\title{
SOCIAL-FAIRNESS PERCEPTION IN NATURAL DISASTER, LEARN FROM LOMBOK: A PHENOMENOLOGICAL REPORT
}

\author{
Filipus Michael Yofrido' ${ }^{1 a}$, Lila Tri Harjana² \\ ${ }^{1}$ Faculty of Medicine, Widya Mandala Catholic University, Surabaya \\ ${ }^{2}$ Department of Anesthesiology and Reanimation, Faculty of Medicine, Universitas Airlangga/Dr. Soetomo Academic Hospital, \\ Surabaya \\ a Corresponding author: filipus@ukwms.ac.id
}

\begin{abstract}
Introduction: Disasters occur in all areas of the world and cause harm to populations, property, infrastructure, economies, and the environment. ${ }^{1}$ Harm to populations includes death, injury, disease, malnutrition, and psychological

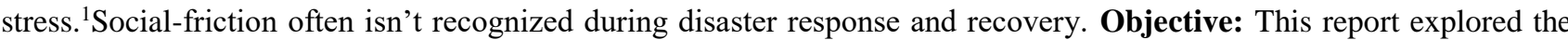
existence of social-friction in disaster situation which able to make recovery more complex. Method: This was qualitative study with phenomenology report approach. The data collection was done by indepth interviewing five inhabitants when doing emergency disaster response two weeks after massive earthquake in North Lombok. Result and discussion: Two out of five inhabitants were Lombok native-people, the rest were immigrant. An inhabitant reported their feeling treated unfair by aid agencies because they received less aid than others. In another chance, when distributing clean-water, we were intercepted, they argue that they got more lack of water than another group who live far distally. Both claimed treated unfair making a dispute friction.Ethnic or social origin, language, religion, gender, age, physical or mental disability, and sexual orientation are just some of the deep-rooted causes of social-friction that can have such a devastating impact on their lives.Social-friction in everyday life rarely endangers lives, but in an emergency situation, it can be life-threatening. It affects not only people's ability to survive the crisis, also their capacity to recover and regain their livelihoods. Conclusion: Risk reduction and preparedness are just as important a part of the process as any aspect of a disaster.Dialogue is fundamental in good programme design, monitoring and evaluation, and systematic efforts to listen to all groups affected by disaster can help pre-empt and remedy unfair-perception.Perhaps,most importantly, understanding and respecting the complex cultural context in which aid agencies are working and using the strategies and mechanismsto detectand minimize social-friction, will result great improvement in the effectiveness and equity of perceived support in humanitarian assistance. ${ }^{2}$
\end{abstract}

Keywords: Disaster, Perceived Support, Psychological Trauma, Social-Friction.

\begin{tabular}{l}
\hline ABSTRAK \\
\hline Pendahuluan: Bencana dapat terjadi dimana saja dan menyebabkan kerusakan pada populasi, properti, infrastruktur, \\
ekonomi, dan lingkungan. ${ }^{1}$ Bahaya terhadap populasi meliputi kematian, cedera, penyakit, malnutrisi, dan stres \\
${\text { psikologis. }{ }^{1} \text { Gesekan sosial seringkali tidak dikenali selama respons dan pemulihan bencana. Tujuan: Laporan ini }}_{\text {mengeksplorasi adanya gesekan sosial dalam situasi bencana yang dapat mengakibatkan pemulihan menjadi lebih }}$ \\
kompleks. Metode: Studi ini merupakan penelitian kualitatif dengan pendekatan laporan fenomenologi. Pengumpulan \\
data dilakukan dengan melakukan indepth interview pada lima penduduk ketika melakukan tanggap darurat bencana dua \\
minggu setelah gempa bumi dahsyat di Kabupaten Lombok Utara. Hasil dan diskusi: Dua dari lima penduduk adalah \\
penduduk asli Lombok, sisanya adalah etnis pendatang. Salah seorang penduduk melaporkan perasaan mereka yang \\
diperlakukan tidak adil oleh lembaga pemberi bantuan karena menerima bantuan lebih sedikit dari kelompok penduduk \\
lainnya. Dalam kesempatan lain, ketika mendistribusikan air bersih, kami dihalangi oleh sekelompok orang, mereka \\
berpendapat bahwa mereka mendapatkan lebih sedikit air daripada kelompok lain yang tinggal lebih jauh. Saling merasa \\
diperlakukan tidak adil membuat terjadinya perselisihan. Asal-usul etnis atau sosial, bahasa, agama, jenis kelamin, usia, \\
kecacatan fisik atau mental, dan orientasi seksual adalah beberapa penyebabgesekan sosial yang dapat memberikan \\
dampak buruk pada kehidupan mereka. Gesekan sosial dalam kehidupan sehari-hari mungkin jarang membahayakan \\
nyawa, tetapi dalam situasi darurat, itu bisa mengancam nyawa. Hal tersebut tidak hanya memengaruhi kemampuan
\end{tabular}


orang untuk selamat dari krisis, juga kapasitas mereka untuk pulih dan mendapatkan kembali kehidupan mereka. Kesimpulan: Pengendalian risiko dan kesiapsiagaan adalah bagian penting dari setiap aspek bencana. Dialog merupakan hal mendasar dalam perancangan program, pemantauan dan evaluasi, dan upaya sistematis untuk mendengarkan semua kelompok korban bencana yang dapat membantu mencegah dan memperbaiki persepsi ketidakadilan. Terlebih yang lebih penting, memahami dan menghormati budaya yang kompleks di mana lembaga pemberi bantuan bekerja serta menggunakan strategi dan mekanisme untuk mendeteksi dan meminimalkan gesekan sosial, akan menghasilkan kemajuan besar dalam efektivitas dan kesetaraan perceived support dalam bantuan kemanusiaan. ${ }^{2}$

Kata kunci: Bencana, Perceived Support, Trauma Psikologis, Gesekan Sosial.

Article info: Received 23 April 2019, Received in revised from 26 June 2019, Accepted 15 July 2019

\section{INTRODUCTION}

Disaster is a sudden, calamitous event that seriously disrupts the function of a community or society and causes human, material, and economic or environmental losses that exceed the society's ability to cope using its own resources. Disaster occurs when a hazard impacts on vulnerable people. Though often caused by nature, disaster can have human origins. Natural hazards are naturally occurring physical phenomena caused either by rapid or slow onset events which can be geophysical (earthquakes, landslides, tsunamis and volcanic activity), hydrological (avalanches and floods), climatological (extreme temperatures, drought and wildfires), meteorological (cyclones and storms/wave surges) or biological (disease epidemics and insect/animal plagues). ${ }^{3}$

Indonesia is a high risk country for disaster. In the World Risk Index (WRI) 2016 Report, Indonesia is categorized as high risk (WRI $10.24 \%$ ) with exposure to natural disasters of $19.36 \%$ (very high) and vulnerability of $52.87 \%$ (high). ${ }^{4}$

In 2018 there were various disasters in Indonesia, one of which was an earthquake on the Lombok Island, West Nusa Tenggara with 564 people dead, approximately 1600 people were injured, and 445 thousand people were evacuated. ${ }^{5}$

Disaster causes harm to populations, property, infrastructure, economies, and the environment. Harm to populations includes death, injury, disease, malnutrition, and psychological stress. ${ }^{1}$

Exposure to disaster is a trigger for [psychological] trauma and other pathological stress. ${ }^{6}$ Studies on post-disaster traumatization processes are still limited. But many researchers have tried to assume the relationship between disaster exposure and the psychological impact of the victim.As early as the 1960s, the disaster sociologist Fritz (1961), suggested a much more positive framework approach to understand psychosocial disaster response patterns. ${ }^{6}$

According to this approach, negative psychological impact on disaster survivors is reduced by their social experience of "therapeutic adjustment". The widespread sharing of danger, loss, and deprivation produces an intimate, primary group solidarity among the survivors, which overcomes social isolation and provides a channel for intimate communication and expression and a major source of physical and emotional support and reassurance (therapeutic community). Other researchers in this tradition have found solidarity to be an universally shared response to crisis, characterized by a reduction in status differences and increased generosity and helpfulness, also the formation of new crosscultural community. The existence of conflict in disaster conditions was still considered a "disaster myth" in early sociological studies. ${ }^{6}$ 
More recent studies provide a new concept, that developed a time-dependent relationship between solidarity and conflict. The temporary peace will tip over into a social conflict at the latest with the advent of external aid. Scarcity of basic resourcesof life, pre-disaster social vulnerability, and perceptions of unfairness increase the egostic attitude of individuals or groups that potentially cause post-disaster friction or conflict. ${ }^{6,7}$

This phenomenology study aimed to show that the social-unfairness perception is potentially able to cause social conflict or friction after natural disaster which was often seen as a disaster myth in some previous views. Through this report, government and aid-agencies involved in disasters are expected not only to pay attention to postdisaster recovery but also to prevent postdisaster conflicts which can further hamper the process of disaster management and recovery.

\section{METHOD}

This was a qualitative study with phenomenological report design. There were five participants in this study who were selected using convenience sampling method based on participant accessibility to the researcher. This study was conducted on August $19^{\text {th }}-23^{\text {rd }}, 2018$ in Bayan Village, Kayangan Sub-District, North Lombok Regency, and the author was a medical volunteer from Surabaya office of Indonesian Red Cross (IRC) disaster response team. The author conducted an interview with unsystematic interview technique to the participants while finding verbal friction among participants during aids distribution.

Phenomenology is a qualitative research method that is widely accepted for describing human beings experience a certain phenomenon. Phenomenology can be defined as the direct investigation and description of phenomena as consciously experienced by people living those experiences (lived spaced, lived body, lived time, and live human relation). It allows the researcher to delve into the perceptions, perspectives, understandings, and feelings of those people who have actually experienced or lived the phenomenon or situation of interest. A phenomenological study attempts to set aside biases and preconceived assumptions about human experiences, feelings, and responses to a particular situation. Phenomenological research is typically conducted through the use of in-depth interviews of small samples of participants (often $5-10$ participants). By studying the perspectives of multiple participants, a researcher can begin to make generalizations regarding what it is like to experience a certain phenomenon from the perspective of those that have lived the experience. ${ }^{8}$

\section{RESULT AND DISCUSSION}

There are five participants in this study, including three women and two men with an average age of 59.4 years. Three out of five are immigrants who have inhabited in North Lombok, while the remaining two are Lombok native people. The native inhabitants of Lombok constitute $85 \%$ of the population of Lombok Island, while the rest are immigrant communities (10\% Bali, 5\% consist of Java, Sumbawa, Chinese and Arabic). Based on the author's observations, most of the immigrant population lives in more remote places from the center of community activities.

Those five inhabitants were massive earthquake victims in Lombok in July August 2018 who settled in Bayan Village, Kayangan District, North Lombok Regency. There was no core family of the participants who died in that earthquake 
There was verbal friction between groups within the same village when the aids distribution process, such as health services, clean water, tents, and bedding. Friction occured because of the feeling not being treated equally and mutual claim of unequal distribution processes.

Participant 4 came to IRC post and enter a complaint that his residential area had not received health services like other areas. When distributing health service and clean water to the area, there were several residents who blocked the distribution process, participant 4 wanted the aids to be distributed at the place where they stopped the aid trucks because they felt that the aids received was insufficient for the residents. Participant 2, participant 3, and participant 5 from another group asked for distributing distally (more remote) because their territory received feweraids.

In the interview, participant 1 (male, 54 years old) said,

"Many organizations came to give assistance, but our area isn't noticed. We have not received aid-distribution for a week. Even though the deeper (farther / more remote) ones get help."

Participant 2 (female, 50 years old) said,

"We often aren't noticed. Many goods are dropped at the tip of the road and not distributed to us by village officials"

Participants 3 (female, 65 years) and 5 (female, 68 years) said,

"Here water pipes are built, water come from [Mount] Rinjani, but we who live closer to Rinjani aren't drained of water."

Participant 4 (male, 60 years) said,

"The truck and water tank must stop here, because in farther community have already received water yesterday. We need more here."
Each group felt treated unfair for the treatment of disaster victims.

Disaster occurs when the risk exceeds the ability of the community to overcome them.Disasters occur when danger comes to vulnerable communities.

$$
\text { Risk }=\frac{\text { hazard } \times \text { vulnerability }}{\text { capacity }}
$$

Vulnerability depends on several factors, including physical, social, economic and environmental factors.Social factors depend on the level of education, security, community peace, access to basic human rights, good governance systems, social equality, and positive cultural values.

The occurrence of natural disasters causes not only physical and biological damage, but also disruption of social equilibrium.In the previous theory, it was stated that the occurrence of natural disasters formed a society's altruistic attitude so that it could reduce even eliminate the friction that previously existed. Solidarity is a sharing response that is common in post-disaster crisis, which is characterized by reduction in status differences, increased generosity, helpfulness, and the formation of new cross-cultural communities. The social dynamics proposed in that theory make post-disaster conflicts or friction considered a disaster myth.

However, Oliver-Smith in 1979 offered a more nuanced perspective, namely timedependent relationships between solidarity and conflict. ${ }^{9}$ In his initial study in the Peru Earthquake (1979), there is the shifting forms of social identification within post-disaster processes. In the rescue situation immediately after the earthquake, when flight wasa question of death or survival, the primary social focus was on rescuing oneselfand one's family. Only in the subsequent early postimpact period did community solidarity and 
cooperation prevail and status differences

However, this "brotherhood of pain" did not last long - it tipped over into conflict, at the latest with the advent of external aid. ${ }^{9}$ Conflict is often coupled with external aid and the sudden availability of material resources that need to be distributed. ${ }^{6}$ Scarcity of basic resources of life, pre-disaster social vulnerability, and unfairness perceptions increase the egostic attitude of individuals or some groups that tend to post-disaster friction or conflict.

In the Social Support Deterioration Deterrence Model (Figure 1), it is hypothesized that the perceived support, not the received support, affects the pattern of society facing stressors. ${ }^{10}$ Society subjective among survivors appearto be suspended. perception on fairness is the major cause of post-disaster conflict. While the amount of aid received (received support) does not have a direct relationship to distress. ${ }^{10}$

This was reflected in the cases that occurred in this report. The perspective of fairness between the aid provider and the recipient were very likely to be different. Participant 4 proactively requested aids distribution because it did not meet the needs of his group. While participant 2, 3, and 5 saw subjectively that the aids much more distributed to other groups. This perception of unfairness which is the part of perceived support can potentially produce friction, especially if there has been social vulnerability before the disaster.

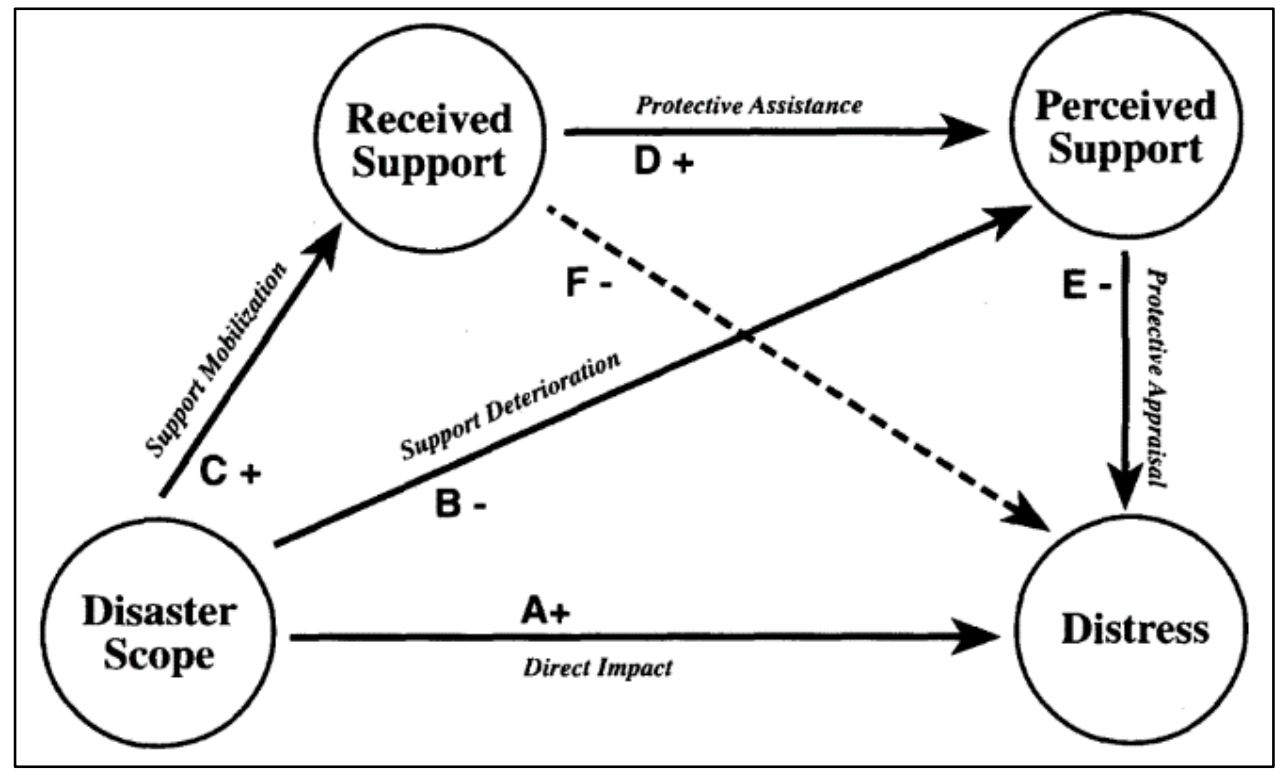

Figure 1. Social Support Deterioration Deterrence Model ${ }^{10}$

Post-disaster social bitterness, as a secondary psychological trauma, may emerge due to dissatisfaction with aid, social support, interpersonal constraints, and conflicts, leading to increased distress. ${ }^{6}$ Besides, the existence of previous friction or conflictcan be strengthened or become a new conflict after a disaster. Ethnic or social origin, language, religion, gender, age, physical or mental disability, and sexual orientation are just some of the deep-rooted causes of social-friction that previously exist. ${ }^{2}$ Post-disaster conflict if isn't handled properly, will have a huge impact. Social-friction in everyday life rarely endangers lives, but in crisis and emergency situation, such as post disaster, can be lifethreatening. ${ }^{2}$

For example, Bangladesh independence after the 1970 cyclone victims had been angry at discrimination from the Pakistan 
government, initiated a civil war in East Pakistan to separate from Pakistan. ${ }^{11}$

The potency of post-disaster social conflict could not be considered further as a myth.The post-disaster social dynamics have varied social impacts, it could reduce pre-disaster conflicts (conflicts reduction in Sri Lanka and Aceh, Indonesia after the 2004 Indian Ocean tsunami ${ }^{7}$ ) or emergence of new conflict (the occurrence of pogrom after the 1923 Tokyo earthquake, $\operatorname{Japan}^{12}$ and the independence of Bangladesh after the 1970 cyclone $^{11}$ ).

What could be learned from the phenomenon shown in this study is that the perception of inequality has the potential to cause social friction. As in the Social Support Deterrence Deterrence theory, the existence of social distress could be reduced by perceived support, not directly dependent to received support. It must be understood by the government and aid agencies that subjective perception of "being helped" is very important to reduce distress caused by disasters. The steps that need to be taken are 1) Identification of pre-disaster social situations; 2) Mitigation and disaster preparation that include social factors which found in identification process as a part of risk (hazard and vulnerability); 3) Periodic assessment and regularly updating of the victim's need; 4) Utilizing the period of temporary peace to increase solidarity and form positive community; 5) Dialogue positively involving all group representatives, especially groups that are often marginalized, such as women, children, elderly, low socioeconomic status, ethnicity and beliefs, or physical and psychological disability groups.

Because post-disaster social risks are often unpredictable and unclear, governments and agencies involved in disasters are expected not only to pay attention to post-disaster recovery, but also to prevent post-disaster conflicts which able to make recovery more complex.
There is still room for further in-depth research by interdisciplinary experts which able to synthesize the concept and mechanism of social dynamics in natural disaster situation.

\section{CONCLUSION}

Natural disasters affect all aspects of human being. Natural disasters could cause social dynamics that are often unpredictable. Natural disasters could bring altruistic solidarity to society, but this condition could only last temporarily, and it is not impossible to turn into social friction and conflict after external aid arrived. Assessing pre-disaster social condition, planning the prevention programs, improving solidarity situation that is formed, and dialogue involving all social groups in order to understand the subjective perceptions of social fairness are the steps that could be taken to minimize post-disaster social distress.

\section{ACKNOWLEDGEMENT}

We acknowledge the Indonesian Red Cross-branch of Surabaya, dr. Lila, Sp.An, dr. Catur, Dr. dr. Inge, M.Psi, for the opportunity and contribution for this paper preparation.

The abstract of this article was presented on the Emergency for Every Doctor 2019 oral presentation without being published in the proceeding book.

\section{Conflict of Interests}

There is no conflict of interest and funding in the writing of this article.The ethical clearance has not been done for this paper.

\section{REFERENCES}

1. Rosen P. Rosen's Emergency Medicine: Concepts and Clinical Practice. 9th ed. (Walls RM, Hockberger RS, Gausche-Hill M, et al., eds.). Philadelphia: Elsevier; 2014.

2. The International Federation of Red Cross and Red Crescent Societies (IFRC). 
Addressing Discrimination in Disasters. Vernier, Switzerland. http://www.ifrc.org/en/news-andmedia/opinions-and-positions/opinionpieces/2007/addressing-discrimination-indisasters/. Published 2007. Accessed January 23, 2019.

3. The International Federation of Red Cross and Red Crescent Societies (IFRC). What is a disaster? https://www.ifrc.org/en/whatwe-do/disaster-management/about-

disasters/what-is-a-disaster/. Accessed January 23, 2019.

4. Garschagen M, Hagenlocher M, Comes M, et al. World Risk Report 2016. August 2016.

http://collections.unu.edu/view/UNU:5763 \#viewMetadata. Accessed January 23, 2019.

5. BBC. Deretan bencana alam mematikan yang menerjang Indonesia sepanjang 2018 BBC News Indonesia. https://www.bbc.com/indonesia/majalah46691586. Published 2018. Accessed January 23, 2019.

6. Zaumseil M, Schwarz S. Cultural Psychology of Coping with Disasters. Vol 9781461493. (Zaumseil M, Schwarz S, von Vacano M, Sullivan GB, PrawitasariHadiyono JE, eds.). New York, NY: Springer New York; 2014. doi:10.1007/978-1-4614-9354-9.

7. Xu J, Wang Z, Shen F, Ouyang C, Tu Y. Natural disasters and social conflict: A systematic literature review. Int J Disaster Risk Reduct. 2016;17:38-48. doi:10.1016/J.IJDRR.2016.04.001.

8. Center for Innovation in Research and Teaching. Phenomenology Research Overview.

https://cirt.gcu.edu/research/developmentr esources/research_ready/phenomenology/p hen_overview. Accessed July 3, 2019.

9. Oliver-Smith A. Post Disaster Consensus and Conflict in a Traditional Society: The 1970 Avalanche of Yungay, Peru. Mass Emergencies. 1979;4:39-52.

10. Norris FH, Kaniasty K. Received and perceived social support in times of stress: A test of the social support deterioration deterrence model. J Pers Soc Psychol. 1996;71(3):498-511. doi:10.1037/00223514.71.3.498

11. History.com. East Pakistan devastated by cylcone. https://www.history.com/thisday-in-history/east-pakistan-devastatedby-cylcone. Published 2010. Accessed January 24, 2019.

12. Tierney KJ. From the Margins to the Mainstream?Disaster Research at the Crossroads. Annu Rev Sociol.2007;33(1): 503-525.

doi:10.1146/annurev.soc.33.040406.13174 3 